\title{
Jarosław Dziuba
}

Uniwersytet Ekonomiczny we Wrocławiu

e-mail: jaroslaw.dziuba@ue.wroc.pl

\section{POLITYKA PODATKOWA}

A AKTYWNOŚĆ INWESTYCYJNA JEDNOSTEK SAMORZĄDU TERYTORIALNEGO W POLSCE NA PRZYKLADZIE MIAST NA PRAWACH POWIATU

\section{TAX POLICY VS. INVESTMENT ACTIVITY}

\section{OF TERRITORIAL GOVERNMENT UNITS IN POLAND} - THE CASE OF CITIES WITH COUNTY RIGHTS

DOI: $10.15611 / \mathrm{pn} .2018 .528 .05$

JEL Classification: H200, H710, K340

Streszczenie: W artykule dokonano identyfikacji rozwiązań prawnych w zakresie władztwa podatkowego jednostek samorządu terytorialnego (JST) w Polsce. Celem opracowania była próba odpowiedzi na pytanie, czy istnieje zależność pomiędzy aktywnością inwestycyjną JST a prowadzoną przez nie polityką podatkową. Ze względu na to, że przyznane samorządom władztwo podatkowe może owocować jedynie obniżeniem dochodów budżetowych, teoretycznie można założyć negatywny wpływ polityki podatkowej na możliwości finansowania inwestycji samorządowych. Przeprowadzona analiza statystyczna wybranych kategorii budżetowych na przykładzie miast na prawach powiatu za lata 2007-2016 nie potwierdziła jednak tej zależności. Nasuwa się wniosek, że decyzje inwestycyjne w JST są podejmowanie niezależnie od decyzji z zakresu polityki podatkowej, która cechuje się dużą inercją i pasywnością.

Słowa kluczowe: samorząd terytorialny, podatki lokalne, polityka podatkowa, inwestycje samorządowe.

Summary: The article identifies legal solutions within the scope of tax authorities of local government units in Poland. The purpose of the study was an attempt to answer the question whether there exists any correlation between the investment activity of local government units and their tax policy. Due to the fact that the tax authority granted to local governments may only result in lower budget revenues, it is theoretically possible to assume a negative impact of tax policy on the possibilities for financing local government investments. The conducted statistical analysis of the selected budget categories based on the example of cities with county rights, covering the years 2007-2016, did not confirm the aforementioned correlation. The conclusion can be drawn that investment decisions are made in local government units regardless of the tax policy decisions, which is characterized by high inertia and passivity.

Keywords: local self-governement, local taxes, tax policy, tax system, local government investments. 


\section{Wstęp}

Ogólnym celem funkcjonowania samorządu terytorialnego jest zaspokajanie potrzeb społeczności lokalnej lub regionalnej. Zapewnienie stałego, nieprzerwanego dostarczania dóbr i usług publicznych i społecznych wymaga m.in. podejmowania działalności inwestycyjnej. Warto podkreślić, że inwestycje samorządowe wpływają nie tylko na jakość usług publicznych i społecznych, lecz także na atrakcyjność ekonomiczną gminy rozpatrywaną z punktu widzenia podmiotów gospodarczych i prowadzonej przez nie działalności gospodarczej.

Realizacja zadań przez jednostki samorządu terytorialnego (JST) polega na ponoszeniu wydatków budżetowych, które muszą mieć zapewnione określone źródła finansowania. Podstawowym źródłem dochodów JST są różnego rodzaju podatki, których cechą jest określone władztwo podatkowe, urzeczywistniające zasadę samodzielności finansowej JST. Pojawia się zatem pytanie, czy ta samodzielność w kształtowaniu dochodów podatkowych, zgodnie z realizowaną przez władze lokalne polityką podatkową, ma swoje konsekwencje w wydatkowej stronie budżetu JST, a zwłaszcza w nieobligatoryjnych wydatkach inwestycyjnych.

Celem niniejszego opracowania jest ocena zależności aktywności inwestycyjnej JST od urzeczywistnianej przez władze lokalne polityki podatkowej. Można postawić hipotezę, że w obecnych ramach prawnych ekspansywna (liberalna) lokalna polityka podatkowa, polegająca na ograniczaniu obciążeń podatkowych mieszkańców i podmiotów gospodarczych, zmniejsza możliwości inwestycyjne JST i negatywnie wpływa na wielkość ponoszonych przez nie wydatków inwestycyjnych. W celu weryfikacji tej hipotezy dokonano identyfikacji rozwiązań prawnych w zakresie władztwa podatkowego i możliwości prowadzenia lokalnej polityki podatkowej oraz przeprowadzono analizę statystyczną dochodów podatkowych i wydatków budżetowych wykonanych przez 66 miast na prawach powiatu w latach 2007-2016.

\section{Wydatki majątkowe w budżetach miast na prawach powiatu}

Wydatki samorządu terytorialnego w nauce finansów i prawa finansowego klasyfikuje się na podstawie wielu kryteriów ekonomicznych. Podstawowym ujęciem wydaje się podział na wydatki bieżące i majątkowe, który opiera się na kryterium przeznaczenia środków. Wydatki majątkowe, w przeciwieństwie do bieżących, zwiększają majątek podmiotu, który ich dokonuje. Według P. M. Gaudemeta, „...nie służą one do przeżycia, lecz prowadzą do poprawy wyposażenia i modyfikacji struktury. [...] Podczas dokonywania tych wydatków nie następuje konsumowanie bogactwa, lecz tylko jego transformacja, a może nawet przygotowanie do stworzenia nowego bogactwa" [Gaudemet, Molinier 2000, s. 60]. Jak zauważa S. Owsiak, na podstawie podziału na wydatki bieżące i majątkowe „... można się zorientować, jaka jest hierarchia potrzeb i/lub preferencje władz publicznych, wyrażane przez kształtowanie proporcji wydatków bieżących i wydatków majątkowych. Między tymi wydatkami 
występuje poniekąd naturalna sprzeczność, gdyż przy danych środkach publicznych te dwa rodzaje wydatków konkurują ze sobą" [Owsiak 2005, s. 242].

$\mathrm{W}$ takim podziale wydatki powinny być ujęte w budżecie JST, co wynika $\mathrm{z}$ art. 236 ustawy o finansach publicznych. Stanowi on m.in. że do kwoty wydatków majątkowych zalicza się wydatki na inwestycje i zakupy inwestycyjne, zakup i objęcie akcji i udziałów oraz wniesienie wkładów do spółek prawa handlowego. Pozostałe wydatki budżetowe są natomiast wydatkami bieżącymi.

Względem wydatków JST obowiązuje zasada samodzielności finansowej, polegająca na swobodzie decydowania o podziale środków budżetowych na wydatki bieżące i majątkowe. Samodzielność ta jest jednak w pewnym zakresie ograniczona przepisami prawa poprzez hierarchizację zadań JST oraz zakres ustawowych zadań obligatoryjnych oraz zleconych, które, mając charakter ,wydatków sztywnych”, powinny być realizowane w pierwszej kolejności [Ruśkowski 2004, s. 220].

W badanym okresie miasta na prawach powiatu zrealizowały wydatki majątkowe o wartości ponad 122 mld zł, co stanowiło prawie 20\% wydatków ogółem (rys. 1). Podobny udział utrzymywał się w każdym z badanych lat. Największy był w 2009 r. (23\%) i od tego czasu można zaobserwować jego spadek do 11,9\% w 2016 roku. W strukturze wydatków majątkowych zdecydowanie dominowały wydatki inwestycyjne z udziałem od 90 do $96,8 \%$. Jest zatem w pełni uzasadnione utożsamianie aktywności inwestycyjnej JST z poziomem ich wydatków majątkowych.

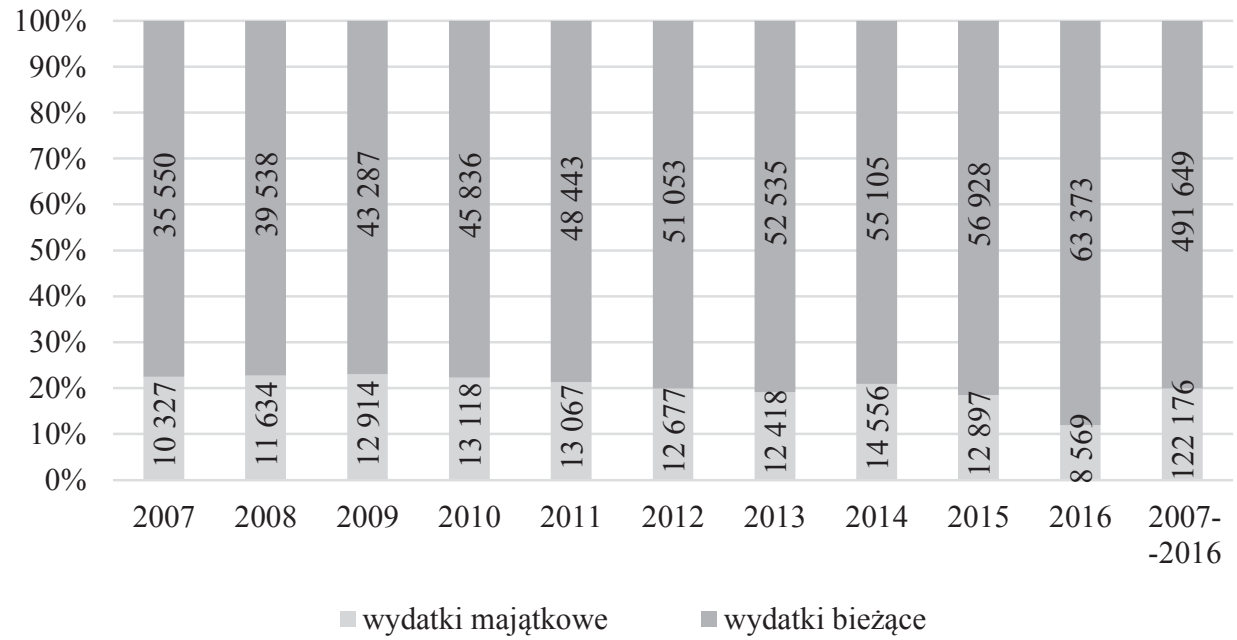

Rys. 1. Struktura wydatków miast na prawach powiatu w latach 2007-2016 (w mln zł)

Źródło: opracowanie własne na podstawie [Główny Urząd Statystyczny (2018)].

Aktywność inwestycyjna JST, mierzona udziałem wydatków majątkowych w wydatkach ogółem, jest determinowana wieloma czynnikami. Można wśród nich 
wymienić występującą lukę infrastrukturalną, czyli różnicę pomiędzy istniejącym stanem infrastruktury a stanem pożądanym, niezbędnym do zaspokojenia potrzeb ludności. Jej stan jest przestrzennie zróżnicowany, a więc i potrzeby inwestycyjne JST nie są jednorodne. Innym czynnikiem może być przyjęta przez władze JST strategia rozwoju, a także wcześniejsza aktywność inwestycyjna. $Z$ jednej strony wpływa ona na stan luki infrastrukturalnej i bieżące potrzeby inwestycyjne, a $z$ drugiej obliguje do kontynuowania rozpoczętego wcześniej projektu inwestycyjnego aż do jego zakończenia.

Niewątpliwie jednak podstawową determinantą aktywności inwestycyjnej JST, a więc zdolności do ponoszenia wydatków majątkowych, jest ich sytuacja finansowa. Wielkość dochodowej strony budżetu warunkuje poziom wydatków budżetowych (w tym majątkowych), natomiast struktura dochodów wpływa na swobodę w kształtowaniu struktury wydatków. Szczególne znaczenie ma tu udział dochodów własnych, w stosunku do których występuje największa samodzielność wydatkowa.

Na zdolność do ponoszenia wydatków majątkowych wpływa wynik operacyjny budżetu, rozumiany jako różnica pomiędzy dochodami bieżącymi a wydatkami bieżącymi JST. Za dochody majątkowe uznaje się dotacje i środki przeznaczone na inwestycje, dochody ze sprzedaży majątku oraz dochody z tytułu przekształcenia prawa użytkowania wieczystego $\mathrm{w}$ prawo własności. Pozostałe dochody zalicza się do dochodów bieżących.

Dodatni wynik, nazywany nadwyżką operacyjną, oznacza, że JST jest w stanie pokryć swoje wydatki bieżące dochodami bieżącymi. Im wyższa jest wartość nadwyżki operacyjnej, tym większe możliwości realizacji przedsięwzięć inwestycyjnych bezpośrednio, przeznaczając kwotę nadwyżki na wydatki majątkowe, lub pośrednio, spłacając zaciągnięte wcześniej zobowiązania na cele inwestycyjne [Ministerstwo Finansów 2017, s. 3]. Warto zauważyć, że występowanie nadwyżki operacyjnej w budżecie zwiększa możliwości inwestycyjne JST, co nie oznacza, że takie musi być jej przeznaczenie. Duży udział wydatków inwestycyjnych w wydatkach ogółem także wcale nie musi wiązać się z wysokimi nadwyżkami operacyjnymi, gdyż wydatki te mogą być pokrywane dochodami majątkowymi lub przychodami. Dostępne w literaturze analizy wskazują na zróżnicowany wpływ nadwyżki operacyjnej na wielkość wydatków majątkowych [Dylewski 2017, s. 82]. Na możliwości finansowania wydatków majątkowych wpływa także wielkość dochodów majątkowych, które często mają celowe przeznaczenie (np. dotacje na inwestycje).

Inwestycje samorządowe znajdują ponadto źródła finansowania w zaciąganych przez JST zobowiązaniach, głównie kredytowych, ale także z tytułu emisji dłużnych papierów wartościowych (obligacji komunalnych). Jednak możliwości zaciągania zobowiązań również są uzależnione od wyniku budżetu bieżącego oraz od poziomu dochodów majątkowych, które stanowią zasadniczy element tzw. indywidualnego wskaźnika zadłużenia, zawartego w art. 243 ustawy o finansach publicznych.

Istotnym źródłem finansowania samorządowych inwestycji są w ostatnich kilkunastu latach także środki unijne. Pozyskanie środków pomocowych z funduszy 
Unii Europejskiej wymaga jednak wniesienia przez beneficjenta pomocy wkładu własnego $\mathrm{w}$ finansowane przedsięwzięcie oraz wiąże się z koniecznością zaangażowania własnych środków (prefinansowania) aż do momentu uzyskania refundacji. W przypadku jednostek samorządu terytorialnego (JST) środki te mogą pochodzić z dochodów, a w sytuacji ich niewystarczalności alternatywą są przychody zwrotne, których zdolność absorpcji także zależy od sytuacji finansowej budżetu bieżącego.

Z powyższych rozważań wynika wniosek, że możliwości ponoszenia wydatków majątkowych przez JST, bez względu na sposób ich finansowania, są bezpośrednio lub pośrednio zależne od wielkości dochodów bieżących. Zalicza się do nich dochody z podatków lokalnych, na których wielkość władze samorządowe mają wpływ dzięki przyznanemu im władztwu podatkowemu i realizowanej polityce podatkowej.

\section{Wladztwo podatkowe i polityka podatkowa miast na prawach powiatu}

Polski system finansów lokalnych został tak ukształtowany, że wśród podatkowych źródeł finansowania JST znaczenie mają jedynie podatki lokalne i udziały w podatkach dochodowych stanowiących dochód budżetu państwa ${ }^{1}$. Wymienione grupy dochodów zasadniczo różnią się m.in. zakresem tzw. władztwa podatkowego, czyli prawnie określonym zakresem uprawnień do podejmowania rozstrzygnięć w sprawach podatkowych. Rozstrzygnięcia te mogą dotyczyć kształtowania elementów konstrukcyjnych podatków (techniki podatkowej), takich jak podmiot, przedmiot i podstawa opodatkowania, stawka i skala podatkowa, zwolnienia i ulgi podatkowe oraz treści stosunku zobowiązaniowego [Kornberger-Sokołowska 2001, s. 83].

Władztwo podatkowe zostało przyznane samorządom przez ustawodawcę tylko w stosunku do podatków lokalnych. Są one źródłem dochodów najniższego szczebla samorządu terytorialnego, czyli gmin, w tym także miast na prawach powiatu. Powszechnie zalicza się do nich podatek od nieruchomości, podatek od środków transportowych, podatek rolny i podatek leśny, dla których organem podatkowym jest organ gminny (wójt, burmistrz lub prezydent miasta), a także podatek dochodowy od osób fizycznych, opłacany w formie karty podatkowej, podatek od spadków i darowizn oraz podatek od czynności cywilnoprawnych, dla których organem podatkowym jest organ państwowy (naczelnik urzędu skarbowego)

Władztwo podatkowe może być realizowane w różnym zakresie przez radę gminy oraz, w zakresie uprawnień wynikających z ustawy Ordynacja podatkowa, przez jej organ wykonawczy, czyli przez wójta, burmistrza lub prezydenta miasta. Elementy konstrukcyjne podatków i sposób, w jaki mogą być one kształtowane przez te organy, wyznaczają możliwości prowadzenia własnej polityki podatkowej. Może być ona rozumiana jako świadome i celowe działania organów gminy, polegające

${ }^{1} \mathrm{Z}$ tą kategorią dochodów nie jest związany żaden element władztwa podatkowego, gdyż należy ono do organów centralnych państwa. 
na doborze źródeł i form gromadzenia dochodów podatkowych, aby osiągnąć cele finansowe, gospodarcze i społeczne [Śmiechowicz, Kozak 2016, s. 471].

Przegląd istniejących instrumentów władztwa podatkowego (tab. 1) prowadzi wniosku, że ma ono charakter częściowy, tzn. dotyczy tylko niektórych podatków i niektórych ich elementów konstrukcyjnych. Ten pewien zakres samodzielności fi-

Tabela 1. Uprawnienia z zakresu władztwa podatkowego gmin

\begin{tabular}{|c|c|c|c|c|}
\hline $\begin{array}{c}\text { Element } \\
\text { techniki } \\
\text { podatkowej }\end{array}$ & $\begin{array}{c}\text { Podatek } \\
\text { od nieruchomości }\end{array}$ & $\begin{array}{c}\text { Podatek } \\
\text { od środków } \\
\text { transportowych }\end{array}$ & Podatek leśny & Podatek rolny \\
\hline Przedmiot & \multicolumn{4}{|l|}{ brak } \\
\hline Podmiot & \multicolumn{4}{|l|}{ brak } \\
\hline Podstawa & \multicolumn{3}{|l|}{ brak } & $\begin{array}{l}\text { możliwość zaliczenia } \\
\text { niektórych wsi do innego } \\
\text { okręgu podatkowego niż } \\
\text { określony dla gminy; } \\
\text { możliwość wystąpienia } \\
\text { z wnioskiem do sejmiku } \\
\text { województwa o zaliczenie } \\
\text { całej gminy do innego okręgu } \\
\text { podatkowego }\end{array}$ \\
\hline Stawki & $\begin{array}{l}\text { ustalanie stawek } \\
\text { podatków do } \\
\text { wysokości } \\
\text { maksymalnych } \\
\text { stawek } \\
\text { ustawowych; } \\
\text { różnicowanie } \\
\text { stawek na } \\
\text { podstawie } \\
\text { kryteriów } \\
\text { przedmiotowych } \\
\end{array}$ & $\begin{array}{l}\text { ustalanie stawek } \\
\text { podatków } \\
\text { w granicach } \\
\text { maksymalnych } \\
\text { i minimalnych } \\
\text { stawek ustawowych; } \\
\text { różnicowanie } \\
\text { stawek na } \\
\text { podstawie kryteriów } \\
\text { przedmiotowych }\end{array}$ & $\begin{array}{l}\text { obniżenie } \\
\text { średniej ceny } \\
\text { skupu drewna, } \\
\text { przyjmowanej } \\
\text { do obliczenia } \\
\text { podatku }\end{array}$ & $\begin{array}{l}\text { obniżenie średniej ceny } \\
\text { skupu żyta, przyjmowanej } \\
\text { do obliczenia podatku }\end{array}$ \\
\hline Ulgi & \multicolumn{3}{|c|}{$\begin{array}{l}\text { odroczenia terminu płatności lub rozłożenia na raty } \\
\text { podatku lub zaległości podatkowej, umorzenia w całości } \\
\text { lub w części zaległości podatkowej, odsetek za zwłokę } \\
\text { lub opłaty prolongacyjnej (przysługujące organowi } \\
\text { podatkowemu na podstawie Ordynacji podatkowej) }\end{array}$} & $\begin{array}{l}\text { odroczenia terminu płatności } \\
\text { lub rozłożenia na raty } \\
\text { podatku lub zaległości } \\
\text { podatkowej, umorzenia } \\
\text { w całości lub w części } \\
\text { zaległości podatkowej, } \\
\text { odsetek za zwłokę lub } \\
\text { opłaty prolongacyjnej } \\
\text { (przysługujące organowi } \\
\text { podatkowemu na podstawie } \\
\text { Ordynacji podatkowej); } \\
\text { ulgi przedmiotowe inne niż } \\
\text { określone w ustawie }\end{array}$ \\
\hline Zwolnienia & \multicolumn{4}{|c|}{ zwolnienia przedmiotowe, inne niż określone ustawowo } \\
\hline
\end{tabular}

Źródło: opracowanie własne na podstawie [Ustawa z 15 listopada 1984 r.; Ustawa z 12 stycznia 1991; Ustawa z 29 sierpnia 1997; Ustawa z 30 października 2002]. 
nansowej przejawia się głównie w możliwości określania wysokości stawek podatkowych, stosowania ulg i zwolnień, umarzania lub rozkładania należności na raty, określania trybu poboru podatku oraz kształtowania w niewielkim zakresie podstawy opodatkowania. Organom miasta nie przysługują natomiast żadne uprawnienia władcze w zakresie kształtowania takich elementów, jak podmiot i przedmiot opodatkowania, a także nakładania nowych podatków.

Kolejną konstatacją jest to, że wykorzystanie narzędzi władztwa podatkowego w obecnym porządku prawnym powodować może wyłącznie zmniejszenie obciążeń podatkowych mieszkańców i podmiotów gospodarczych. Politykę obniżania podatków określa się w literaturze jako ekspansywną [Wernik 2007, s. 139], liberalną, a czasem populistyczną, jeśli obniżki dotyczą obciążeń tylko osób fizycznych, czy też stymulującą w przypadku obniżek podatków dla podmiotów gospodarczych [Swianiewicz 2004, s. 257]. Gminy realizujące taką politykę ponoszą konsekwencje w postaci zmniejszenia bieżących dochodów budżetowych z tego źródła.

Ocena tych konsekwencji wymaga porównania finansowych skutków zastosowania instrumentów władztwa podatkowego z dochodami uzyskanymi z podatków lokalnych. Relacja tych wielkości wskazuje, jaki mógłby być względny przyrost dochodów z tego źródła, gdyby tych kompetencji nie było lub miasta $\mathrm{z}$ nich nie skorzystały. Zmiana tych relacji w czasie świadczy natomiast o aktywności władz lokalnych w prowadzeniu polityki podatkowej.

W całym badanym okresie lat 2007-2016 finansowe skutki polityki podatkowej miast na prawach powiatu stanowiły średnio 7,3\% dochodów z podatków lokalnych tego sektora. Biorąc pod uwagę fakt, że podatki lokalne przynoszą tylko ok. 14\% dochodów ogółem, instrumenty władztwa podatkowego uszczupliły tę najszerszą kategorię dochodów średnio tylko o 1\%, co można uznać za poziom marginalny. W każdym $\mathrm{z}$ badanych lat osobno relacje te były podobne. Analiza jednostkowa budżetów wykazuje jednak istotne zróżnicowanie tych wskaźników (tab. 2). Najwyższa relacja względem dochodów z podatków lokalnych (33\%) wystąpiła w mieście Biała Podlaska, natomiast najniższa $(1,4 \%) \mathrm{w}$ Warszawie. Mediana wyniosła ok. $11 \%$, pierwszy kwartyl $-8 \%$, a trzeci kwartyl - 15\%. Podobne wielkości miar położenia wystąpiły

Tabela 2. Zróżnicowanie finansowych skutków polityki podatkowej miast na prawach powiatu w relacji do ich dochodów z podatków lokalnych w latach 2007-2016 (w \%)

\begin{tabular}{|l|r|r|r|r|r|r|r|r|r|r|r|}
\hline & 2007 & 2008 & 2009 & 2010 & 2011 & 2012 & 2013 & 2014 & 2015 & 2016 & $\begin{array}{c}2007- \\
-2016\end{array}$ \\
\hline $\max$ & 42 & 27 & 42 & 38 & 54 & 43 & 34 & 44 & 37 & 26 & $\mathbf{3 3}$ \\
\hline min & 3 & 2 & 1 & 0 & 0 & 1 & 1 & 1 & 2 & 1 & $\mathbf{1}$ \\
\hline q1 & 9 & 7 & 8 & 8 & 8 & 6 & 6 & 6 & 7 & 5 & $\mathbf{8}$ \\
\hline q2 & 12 & 10 & 11 & 12 & 11 & 10 & 10 & 11 & 11 & 9 & $\mathbf{1 1}$ \\
\hline q3 & 17 & 15 & 16 & 19 & 19 & 15 & 16 & 17 & 16 & 11 & $\mathbf{1 5}$ \\
\hline
\end{tabular}

Źródło: opracowanie własne na podstawie [Ministerstwo Finansów 2008-2017]. 
także w każdym z badanych lat z osobna. Największym zróżnicowaniem charakteryzowała się maksymalna wartość wskaźnika, która wahała się w przedziale od 26 do 56\% i w większości lat wystąpiła w Białej Podlaskiej.

Polityka podatkowa miast cechowała się ponadto dość dużą pasywnością i brakiem istotnych zmian w jej prowadzeniu. Statystycznie świadczą o tym niskie współczynniki zmienności omawianej relacji dla poszczególnych jednostek. W aż 51 przypadkach współczynniki te były niższe niż $20 \%$, co świadczy o małej zmienności polityki podatkowej, a tylko w 2 przypadkach współczynnik zmienności osiągnął wartość powyżej $30 \%$, co i tak należy uznać za zmienność przeciętną.

Przedstawione informacje i dane wskazują, że lokalna polityka podatkowa jest w opozycji z podstawową funkcją podatków, jaką jest funkcja fiskalna (dochodowa). Jej zadaniem jest dostarczanie dochodów budżetowych w wielkości wystarczającej do pokrycia wydatków budżetowych, będących pochodną zakresu zadań danego szczebla władzy publicznej. Pojawia się zatem pytanie o powody stosowania instrumentów władztwa podatkowego, a więc także o cele lokalnej polityki podatkowej.

Ogólnie można stwierdzić, że dzięki takim uprawnieniom władczym podatki lokalne, poza funkcją wyłącznie fiskalną, pełnią także inne funkcje, np. stymulacyjną czy społeczną. Konkretne cele tak realizowanej polityki podatkowej przez władze samorządowe są wielorakie. W literaturze, obok podstawowych celów fiskalnych, wskazuje się przede wszystkim takie motywy, jak:

- stymulowanie lokalnego rozwoju gospodarczego, czyli poprzez obniżanie podatków przyciągnięcie na dane terytorium mieszkańców i firm, ewentualne zatrzymanie ich odpływu, a przez to kształtowanie bazy podatkowej,

- utrzymanie lub zwiększenie kapitału politycznego - poprzez zaspokojenie oczekiwań mieszkańców będących wyborcami w zakresie stawek podatkowych [Łukomska, Swianiewicz 2015, s. 109].

Te dwa cele polityki podatkowej wiążą się z możliwym zjawiskiem konkurencji podatkowej występującej pomiędzy JST. Może ona przybrać charakter klasyczny, a więc konkurencji o bazę podatkową, oraz charakter porównawczy, mający na celu dopasowanie obciążeń podatkowych do poziomów występujących w sąsiednich gminach, aby uniknąć negatywnej oceny wyborców.

W zakresie celów gospodarczych stosowanie preferencji podatkowych, którymi w istocie są narzędzia lokalnej polityki podatkowej, może się przyczynić do realizacji różnych programów gospodarczych, np. w ramach pomocy regionalnej na wpieranie nowych inwestycji lub tworzenie nowych miejsc pracy. Celem może być także poprawa jakości usług komunalnych poprzez stosowanie preferencji względem przedmiotów opodatkowania związanych ze świadczeniem tego typu usług (np. obiekty związane z poborem wody i oczyszczaniem ścieków, ochroną przeciwpożarową itp.) [Śmiechowicz, Kozak 2016, s. 471-472]. Inną grupą przesłanek aktywnej polityki podatkowej mogą być względy społeczne (np. wspieranie działalności charytatywnej, rekreacyjnej, sportowej, edukacyjnej, kulturalnej, związanej z ochroną zabytków, a także chęć ulżenia indywidualnym podatnikom ze względu na ich 
trudną sytuację materialną) i ekologiczne (ochrona przyrody, hodowla zwierząt, preferowanie ekologicznych systemów ogrzewania i transportu), zgodnie z koncepcją zrównoważonego rozwoju [Dziuba 2013, s. 29-34].

Badania przeprowadzone przez P. Swianiewicza i J. Łukomską wskazują, że pomimo tej dużej różnorodności potencjalnych celów realizowanej przez JST polityki podatkowej w ramach bardzo ograniczonych prawnie narzędzi, w świadomości lokalnych polityków podstawowe znaczenie ma jednak cel fiskalny. Najważniejszym wskazywanym w badaniu motywem polityki podatkowej jest zabieganie o wpływy budżetowe, czyli chęć ich zwiększenia lub utrzymania takiego strumienia, który pozwoli na równowagę budżetu bieżącego i realizację niezbędnych inwestycji [Łukomska, Swianiewicz 2015, s. 110]. Inne badania z kolei wskazują także na nieskuteczność lokalnej polityki podatkowej w stymulowaniu wzrostu bazy podatkowej (por. [Swianiewicz 2004, s. 259; Korolewska 2014, s. 106; Satoła 2014, s. 244]) i brak związku tej polityki z tzw. cyklem wyborczym i zabieganiem władz o poparcie mieszkańców [Łukomska, Swianiewicz 2015, s. 82]. Można z tego wyciągnąć wniosek, że fiskalne nastawienie władz lokalnych w stosunku do polityki podatkowej JST jest poniekąd racjonalne. Skoro nie ma naukowych dowodów na to, że obniżanie podatków lokalnych w warunkach polskich przynosi pożądane skutki gospodarcze, społeczne czy ekologiczne, a także polityczne, to być może bardziej rozsądne są próby osiągnięcia podobnych celów z wykorzystaniem bezpośrednich wydatków budżetowych, które znajdą pokrycie m.in. w dochodach z podatków lokalnych, realizowanych w dużym wymiarze w ramach restrykcyjnej polityki podatkowej.

Pojawia się tu pytanie, czy takie prodochodowe podejście i jednocześnie odrzucenie polityki podatkowej jako narzędzia bezpośredniej stymulacji zjawisk rynkowych i politycznych ma swoje konsekwencje w koniecznej przecież, prorozwojowej polityce wydatkowej JST. Głównym jej miernikiem jest poziom wydatków majątkowych i ich udział w wydatkowej stronie budżetu. Celem dalszej części artykułu będzie zatem próba zbadania związku statystycznego pomiędzy aktywnością miast na prawach powiatu w zakresie wykorzystania instrumentów władztwa podatkowego a poziomem ich finansowych możliwości inwestycyjnych i faktycznej aktywności inwestycyjnej.

\section{Analiza zależności aktywności inwestycyjnej i fiskalnych skutków władztwa podatkowego miast na prawach powiatu}

W celu weryfikacji postawionej we wstępie artykułu hipotezy dokonano analizy zależności pomiędzy wskaźnikiem fiskalnych skutków władztwa podatkowego ogółem w relacji do dochodów z podatków lokalnych miast na prawach powiatu w latach 2007-2016 a wybranymi wskaźnikami, charakteryzującymi ich aktywność inwestycyjną oraz możliwości inwestycyjne, takimi jak:

- $\quad$ udział wydatków majątkowych w wydatkach ogółem (W1), 
- udział nadwyżki operacyjnej w dochodach ogółem (W2),

- relacja nadwyżki operacyjnej powiększonej o dochody majątkowe do wydatków majątkowych - tzw. wskaźnik samofinansowania (W3).

Pierwszy ze wskaźników pokazuje aktywność inwestycyjną jednostek, a więc jaki procent wydatków ogółem stanowią wydatki majątkowe. Drugi z nich wskazuje na potencjalne zdolności do finansowania własnymi środkami, a więc bez konieczności zaciągania nowych zobowiązań, wydatków majątkowych, zwiększenia wydatków bieżących oraz spłaty istniejących zobowiązań. Trzeci ze wskaźników wskazuje stopień, w jakim JST finansuje inwestycje środkami własnymi, czyli zdolność do samofinansowania inwestycji. Potwierdzenie postawionej na wstępie artykułu hipotezy wymaga wykazania silnej ujemnej zależności tych wskaźników ze wskaźnikiem fiskalnych skutków władztwa podatkowego ogółem w relacji do dochodów z podatków lokalnych. Tabela 3 przedstawia obliczone współczynniki korelacji liniowej Pearsona dla omawianych wskaźników.

Tabela 3. Współczynniki korelacji liniowej Pearsona pomiędzy wskaźnikiem fiskalnych skutków władztwa podatkowego w relacji do dochodów z podatków lokalnych a wskaźnikami W1, W2, W3

\begin{tabular}{|c|r|r|r|r|r|r|r|r|r|r|r|}
\hline Wskaźnik & 2007 & 2008 & 2009 & 2010 & 2011 & 2012 & 2013 & 2014 & 2015 & 2016 & $\begin{array}{r}2007- \\
-2016\end{array}$ \\
\hline W1 & $-0,38$ & $-0,30$ & $-0,17$ & $-0,19$ & $-0,20$ & $-0,12$ & $-0,16$ & $-0,12$ & $-0,02$ & $-0,22$ & $-\mathbf{0 , 3 0}$ \\
\hline W2 & $-0,31$ & $-0,42$ & $-0,29$ & $-0,32$ & $-0,27$ & $-0,02$ & $-0,22$ & $-0,40$ & $-0,15$ & $-0,12$ & $-\mathbf{0 , 2 9}$ \\
\hline W3 & 0,15 & $-0,07$ & $-0,15$ & $-0,15$ & 0,01 & 0,07 & $-0,16$ & 0,01 & $-0,02$ & 0,04 & $\mathbf{0 , 0 4}$ \\
\hline
\end{tabular}

Źródło: opracowanie własne.

Analiza obliczonych współczynników korelacji dla wskaźników W1 i W2 wskazuje co prawda na zależność ujemną na poziomie ok. $-0,3$ dla całego badanego okresu, ale zgodnie z przyjętymi w analizach statystycznych normami ich poziom wskazuje na zależność liniową wyraźną, lecz niską. W przypadku wskaźnika W3 praktycznie brakuje związku liniowego pomiędzy badanymi wskaźnikami [Ostasiewicz i in. 1999, s. 276]. Badając korelacje dla każdego roku z osobna, widać duże zróżnicowanie zależności statystycznej, niemniej jednak współczynniki potwierdzają jej niski poziom.

Obliczenia te nie pozwalają uznać postawionej we wstępie pracy hipotezy za prawdziwą. Można zatem stwierdzić, że polityka podatkowa miast na prawach powiatu, owocująca zmniejszeniem ich dochodów budżetowych, nie tylko nie osłabia ich możliwości inwestycyjnych i nie wpływa negatywnie na wielkość ponoszonych przez nie wydatków inwestycyjnych, lecz także nie ma z tym cechami większego związku. Brak istotnego statystycznie związku można uzasadnić niewielkim wpływem skutków polityki podatkowej na poziom dochodów ogółem badanych jednostek, a także na poziom realizowanej nadwyżki operacyjnej. Również w relacji do wielkości wydatków majątkowych finansowe skutki polityki podatkowej 
miast stanowią niewielki udział, mieszczący się w przedziale od 4,8 do $7,4 \% \mathrm{w}$ poszczególnych latach. Jest to pochodna zarówno rozwiązań prawnych, przyznających samorządom niewielkie władztwo podatkowe, ograniczone tylko do 4 podatków i nielicznych elementów techniki podatkowej, jak i względnie restrykcyjnej polityki podatkowej omawianych jednostek. Miasta na prawach powiatu charakteryzują się bowiem znacznie niższym poziomem relacji finansowych skutków polityki podatkowej do dochodów z podatków lokalnych i dochodów ogółem niż inne typy gmin.

\section{Zakończenie}

Zgodnie z aktualnymi rozwiązaniami prawnymi w zakresie władztwa podatkowego JST prowadzona przez nie liberalna polityka podatkowa w ujęciu budżetowym może spowodować jedynie obniżanie dochodów z wybranych podatków. Teoretycznie można więc założyć jej negatywny wpływ na poziom dochodów bieżących oraz nadwyżki operacyjnej. W konsekwencji powinno to powodować zmniejszenie możliwości finansowania zadań i wpływać ujemnie przede wszystkim na poziom wydatków fakultatywnych, do których zalicza się wydatki majątkowe.

Przeprowadzona $\mathrm{w}$ artykule analiza nie potwierdza tej zależności. W grupie miast na prawach powiatu, zarówno biorąc pod uwagę długi czasokres, jak i w każdym z badanych lat z osobna, nie widać silnych statystycznych związków pomiędzy prowadzoną polityką podatkową, mierzoną jej finansowymi skutkami w relacji do dochodów, a aktywnością i finansowymi możliwościami inwestycyjnymi tych jednostek.

Polityka podatkowa cechuje się dość dużą inercją, a władze samorządowe niechętnie dokonują w niej gwałtownych zmian, podyktowanych potrzebami wydatkowymi. Wydaje się, że decyzje inwestycyjne w JST są podejmowanie niezależnie od decyzji z zakresu polityki podatkowej, które często ze względów politycznych schodzą na drugi plan debaty publicznej w JST [Łukomska, Swianiewicz 2015, s. 157].

\section{Literatura}

Dylewski M., 2017, Nadwyżka operacyjna a decyzje finansowe jednostek samorzadu terytorialnego, ANNALES UMCS, Sectio H, OECONOMIA, vol. 51, No 6, Wydawnictwo UMCS, Lublin.

Dziuba J., 2013, The concept of sustainable development in tax policy of cities with county rights referring to property tax in Poland, [w:] Finance and Accountancy for Sustainable Development: Sustainable Finance, red. G. Borys, M. Solarz, Research papers of Wrocław University of Economics No 302, Publishing House of University of Economics, Wrocław, s. 26-36.

Gaudemet P.M., Molinier J., 2000, Finanse publiczne, Polskie Wydawnictwo Ekonomiczne, Warszawa. Główny Urząd Statystyczny, Bank Danych Lokalnych, www.stat.gov.pl (14.05.2018).

Kornberger-Sokołowska E., 2001, Decentralizacja finansów publicznych a samodzielność finansowa jednostek samorzadu terytorialnego. Liber, Warszawa. 
Korolewska M., 2014, Polityka podatkowa gmin i miast na prawach powiatu w zakresie podatku od nieruchomości a wspieranie przedsiębiorczości przez samorząd terytorialny, Studia BAS, nr 1 (37), s. 85-108.

Łukomska J., Swianiewicz P., 2015, Polityka podatkowa władz lokalnych w Polsce, Municipium SA, Warszawa.

Ministerstwo Finansów, 2008-2017, Sprawozdania z wykonania budżetów miast na prawach powiatu w latach 2007-2016, Warszawa (www.mf.gov.pl).

Ministerstwo Finansów, 2017, Nadwyżka operacyjna w jednostkach samorzadu terytorialnego $w$ latach 2014-2016, Warszawa (www.mf.gov.pl).

Ostasiewicz S., Rusnak Z., Siedlecka U., 1999, Statystyka. Elementy teorii i zadania, Wydawnictwo AE we Wrocławiu, Wrocław.

Owsiak S., 2005, Finanse publiczne. Teoria i praktyka, Wydawnictwo Naukowe PWN, Warszawa.

Ruśkowski E., 2004, Finanse lokalne w dobie akcesji, Dom Wydawniczy ABC, Warszawa.

Satoła Ł., 2014, Wpływ polityki podatkowej gmin na poziom przedsiębiorczości (na przykładzie podatku od nieruchomości), Nierówności Społeczne a Wzrost Gospodarczy, nr 40, Wydawnictwo Uniwersytetu Rzeszowskiego, Rzeszów, s. 238-247.

Swianiewicz P., 2004, Finanse lokalne - teoria i praktyka, Municipium SA, Warszawa.

Śmiechowicz J., Kozak P., 2016, Diagnoza skutków polityki podatkowej gmin w Polsce w latach 2003-2015, Prace Naukowe Uniwersytetu Ekonomicznego we Wrocławiu nr 451, Finanse publiczne, red. J. Sokołowski, A. Żabiński, Wrocław, s. 468-478.

Ustawa z 12 stycznia 1991 r. o podatkach i opłatach lokalnych, Dz.U. 2017, poz. 1785 ze zm.

Ustawa z 15 listopada 1984 r. o podatku rolnym, Dz.U. 2017, poz. 1892.

Ustawa z 27 sierpnia 2009 r. o finansach publicznych, Dz.U. 2017, poz. 2077.

Ustawa z 29 sierpnia 1997 r. Ordynacja podatkowa, Dz.U. 2018, poz. 800.

Ustawa z 30 października 2002 r. o podatku leśnym, Dz.U. 2017, poz. 1821.

Wernik A., 2007, Finanse publiczne, PWE, Warszawa. 